\title{
Investigating Land Surface Effects on the Moisture Transport over South America with a Moisture Tagging Model
}

\author{
ZHAO YANG \\ Department of Atmospheric Sciences, University of Illinois, Urbana-Champaign, Urbana, Illinois, and Pacific \\ Northwest National Laboratory, Richland, Washington \\ FRANCINA DOMINGUEZ \\ Department of Atmospheric Sciences, University of Illinois, Urbana-Champaign, Urbana, Illinois
}

(Manuscript received 23 October 2018, in final form 6 June 2019)

\begin{abstract}
Land-atmosphere interactions are a critical component of precipitation processes within the Amazon basin and La Plata River basin (LPRB) in South America. Two of the possible pathways through which the land surface can affect precipitation are 1) by changing the amount of moisture available for precipitation (moisture recycling) and 2) by changing the atmospheric thermal structure and consequently affecting circulation patterns. In this study, the Weather Research and Forecasting (WRF) Model with embedded water vapor tracers (WVT) is used to disentangle these relative contributions, with a particular focus on the precipitation of LPRB. Using WRF-WVT we track the moisture that originates from the Amazon basin over a 10 -yr period. It is estimated that Amazon evapotranspiration (ET) contributes to around $30 \%$ of the total precipitation over the Amazon and around $16 \%$ over the LPRB. Focusing on large-scale circulation patterns that transport moisture into the LPRB, we show that land surface conditions in northwestern Argentina are critical for the meridional transport of moisture to higher latitudes via Chaco jet events (CJEs). Warm surface air temperature associated with dry soil moisture over northwestern Argentina is linked to enhanced CJE northerly low-level winds that intensify moisture transport by changing continental-scale circulation patterns. WRF sensitivity tests confirm that soil moisture variations over this region affect meridional moisture transport.
\end{abstract}

\section{Introduction}

The pathways by which terrestrial moisture can affect precipitation range from the local to the global scale (Koster et al. 2004; Koster et al. 2016; Santanello et al. 2018, and references therein). At the local scale, soil moisture affects the partitioning of energy fluxes, the properties of the planetary boundary layer (PBL), and hence the thermal structure/instability profile of the atmosphere (e.g., Wei et al. 2016a). The mechanisms are complex because as soil moisture increases, precipitation can either increase or decrease through positive feedbacks or negative feedbacks within the boundary layer (Pal and Eltahir 2001; Findell and Eltahir 1997, 2003; Koster et al. 2004, 2006; Cook et al. 2006; Taylor et al. 2011). Several studies have found evidence of negative feedbacks as increasing soil moisture can result

Corresponding author: Zhao Yang, zhao.yang@pnnl.gov in more latent cooling and an increased vertical gradient in equivalent potential temperature, which implies more stable atmospheric conditions (Cook et al. 2006). Additionally, reduced soil moisture can enhance mesoscale convergence and lead to increased precipitation (Taylor et al. 2011; Cook et al. 2006). On the other hand, high soil moisture tends to increase moist static energy in the planetary boundary layer, decrease PBL height, and reduce the amount of entrained air from the free atmosphere above. As a result, high soil moisture can increase the possibility of convective rainfall events (Eltahir 1998). Over the Amazon forest (red outline in Fig. 1), Wright et al. (2017) find strong evidence of positive feedbacks as transpiration from the forest moistens and destabilizes the atmosphere during the wet-season onset. This positive relation is also found over the northeastern portion of La Plata River basin (LPRB; blue outline in Fig. 1; Ruscica et al. 2015). 


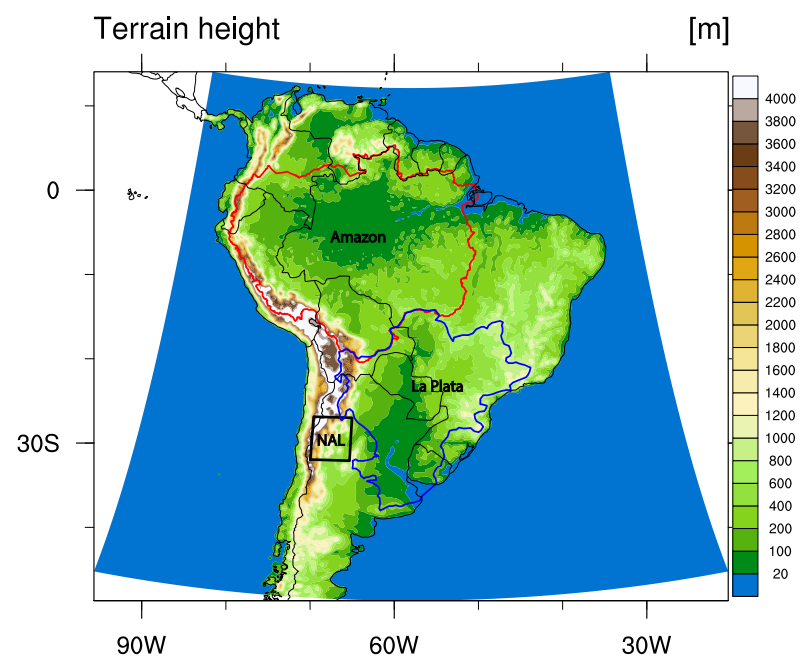

FIG. 1. The model domain with shading indicates elevation (m); delineated areas represent the boundary of the Amazon River basin (red) and the La Plata River basin (blue). The black box indicates the core region of the northwestern Argentinean low (NAL).

At larger scales, enhanced terrestrial moisture can increase atmospheric specific humidity through evapotranspiration (ET) and later contribute to precipitation as this moisture is advected to other regions. The role of ET as a source of moisture for precipitation has been investigated for many regions of the world (Brubaker et al. 1993; Dirmeyer and Brubaker 2006, 2007; Gimeno et al. 2010, 2012; van der Ent et al. 2010, 2013; Martinez and Dominguez 2014; Dominguez et al. 2016; Hu and Dominguez 2015). The pioneering work of Salati et al. (1979) highlighted the importance of the Amazon forest transpiration for precipitation. This understanding came at a time of rapid rates of deforestation in the basin (Nepstad et al. 2009; Soares-Filho et al. 2006) and motivated many studies focused on the quantification of precipitation within the Amazon basin that originates from local ET (i.e., precipitation recycling). A relevant study, by Spracklen et al. (2012), shows that when air passes over more vegetated areas, it could produce more precipitation over the tropical land areas. We refer to precipitation recycling as the fraction of precipitation falling in an area that originates as ET from the same area. It describes how precipitation in a particular region depends on ET from local origin (van der Ent et al. 2010). We adopt this definition of precipitation recycling throughout this study.

Previous studies find that precipitation recycling within the Amazon basin ranges between 14\% and 35\% (Brubaker et al. 1993; Eltahir and Bras 1994; Zemp et al. 2014), with the largest values in the southwestern part of the basin toward the Andes Mountains and the smallest values in the northeastern Amazon basin (Eltahir and Bras 1994; van der Ent et al. 2010; Dirmeyer and Brubaker 2007). However, this moisture does not only remain within the Amazon forest but can also travel to other terrestrial or oceanic regions. In fact, it has been estimated that about $23 \%$ of the precipitation in the LPRB during the wet season and $21 \%-25 \%$ during the dry season originates from the Amazon (Zemp et al. 2014; Martinez and Dominguez 2014). It is important to note, however, that these estimates are based on analytical models that assume a well-mixed atmosphere, which can lead to inaccuracies (van der Ent et al. 2013; Dominguez et al. 2016).

How can the moisture from the Amazon penetrate into southern South America traveling distances on the order of $3000 \mathrm{~km}$ ? The main mechanism for this tropical-extratropical exchange is the semi-permanent South American low-level jet (SALLJ), a narrow area of high winds to the east of the Andes Mountains that is known for bringing moisture-laden air into southern Brazil and northern Argentina (Marengo 2006; Vera et al. 2006; Arraut et al. 2012). A subset of the SALLJs have extreme southward extents and are able to penetrate south of $25^{\circ} \mathrm{S}$; these are called Chaco jet events [CJEs; e.g., see Fig. 8 in Salio et al. (2002)]. Chaco jet penetration toward high latitudes is associated with a deepening of the northwestern Argentinean low (NAL; Salio et al. 2002). During the austral summer season, the NAL is driven by surface warming processes related to surface fluxes (Seluchi et al. 2003). Using the European Centre for Medium-Range Weather Forecasts (ECMWF) reanalysis and focusing on the composite of CJEs, Salio et al. (2002) found that CJEs are associated with deepening of low-level pressure centered around the NAL region. Seluchi et al. (2003) studied the life cycles of the NAL in both austral summer and winter and concluded that the NAL in the summer has a significant diurnal cycle that is dominated by local surface warming. Investigating the same event, Saulo et al. (2004) analyzed the Chaco jet event associated with the summer NAL. The authors found that local effects exert strong influence on the diurnal cycle of the low-level winds in the first day and a half of the simulation. These previous studies have demonstrated a possible linkage: surface conditions near the NAL region are closely related to low-level pressure gradients and circulation features that are important for moisture transport to the higher latitudes. It is expected that variations in surface conditions within the NAL region could modify the moisture-laden low-level winds and further affect precipitation in southern South America. The impact of soil moisture in subtropical South America on low-level circulation and precipitation is studied by Saulo et al. 
(2010) for a 10-day NAL event. In this study, systematic change in the low-level circulation is only found in the experiments with domain-wide increase or decrease of soil moisture. In the experiment with soil moisture decrease over the NAL region, no consistent wind anomaly was found. This finding is somewhat inconsistent with the physical link proposed in previous studies. Notably, the previous mentioned studies are eventbased; it is imperative to extend the analysis to longer periods to test whether soil moisture anomalies in the NAL region indeed affect circulation patterns.

In summary, evidence suggests that two of the ways in which surface fluxes can affect precipitation over South America are 1) by providing moisture for precipitation and 2) by changing the atmospheric thermal structure and consequently affecting circulation patterns. In this work we will first analyze the role of the Amazon forest in providing moisture for precipitation throughout the South American continent. It is important to highlight that, unlike most studies that focused on the impact of Amazonian evapotranspiration on Amazonian precipitation (Salati et al. 1979; Eltahir and Bras 1994), we are primarily interested in the remote influence of Amazonian moisture on the LPRB. In addition, the second mechanism we investigate is the role of land surface fluxes in driving large-scale circulation processes that transport Amazonian moisture deep to southern South America, specifically through the low-level jet. The overarching goal of this work is to quantify this dual contribution of land surface fluxes to precipitation over South America, and in particular the LPRB. To do this, we use the newly developed Weather Research and Forecasting (WRF) Model with the added capability of water vapor tracers (WRF-WVT) (Insua-Costa and Miguez-Macho 2018) to simulate a 10-yr climatology over South America from 2004 to 2013. This model is used to "tag" the moisture that originates as ET from the Amazonian forest, and follow it in space and time as simulated by the model. This modeling strategy is analogous to adding a "dye" in the model's hydrological cycle (Sodemann et al. 2009). In this way, we are able to overcome some of the drawbacks of previous studies using analytical models, and delve into the details of the mechanisms of moisture transport.

\section{Methods}

\section{a. Model description of WRF-WVT}

Water vapor tracers (WVTs) have been incorporated into the WRF-WVT (Miguez-Macho et al. 2013; InsuaCosta and Miguez-Macho 2018). This tool allows the user to trace moisture that originates as evapotranspiration from a tagged region. The tracer is numerically treated in the same way as moisture in the simulation, except for its sources, which are limited to the areas of interest. In other words, evapotranspiration that originates from a selected region will be numerically "tagged" as it undergoes the same physical processes as total moisture such as advection, convection, phase change, and so on. The WRFWVT will save tracer moisture-related variables. Physical parameterization used in the WRF-WVT include the Yonsei University (YSU) parameterization for turbulent mixing (Hong and Pan 1996), the Kain-Fritsch (KF) parameterization for subgrid-scale convection (Kain and Fritsch 1990), the WRF single-moment six-class microphysics scheme (WSM6; Hong and Lim 2006) for phase change and precipitation generation, and the Noah land surface model with multiparameterization options (Noah-MP; Niu et al. 2011). In particular, tracer moisture advection and horizontal diffusion follow the exact same transport equations in WRF for scalar variables, including water vapor and all micrometeors. Tracer moisture changes phase and is converted to precipitation in the same proportion as full moisture does in all cases. All tracer moisture species are generated or converted from one to another and to precipitation mimicking their full moisture counterparts.

In the study, the Amazon basin is defined as a source region (red outline in Fig. 1) and its ET is tagged (i.e., tracer) throughout its lifetime until it precipitates out of the atmosphere. Tracer precipitation is defined as the precipitation that originates as source region ET. For instance, tracer precipitation over the La Plata is the amount of precipitation over the La Plata that originates as ET from the Amazon. The tracer precipitation ratio $r_{p}$ is defined as the fraction of tracer precipitation to total precipitation. In the Amazon, the tracer precipitation ratio is identical to the precipitation recycling ratio. Similarly, tracer water vapor in the atmosphere column is the amount of water vapor that originates as ET from the Amazon, and the tracer water vapor ratio $r_{\mathrm{pw}}$ is the ratio of vertically integrated tracer water vapor from the Amazon to vertically integrated total water vapor in the atmospheric column.

A groundwater scheme is also included in the NoahMP land surface model to consider the interactions between the soil column and the shallow aquifers (Barlage et al. 2015; Martinez et al. 2016). The groundwater scheme was developed by Miguez-Macho et al. (2007) and recently implemented in the Noah-MP land surface model (Barlage et al. 2015) and coupled to WRF (Martinez et al. 2016). Unlike the free drainage scheme, this groundwater scheme includes a representation of a shallow aquifer and its interactions with the soil column above. As shown in Martinez et al. (2016), the consideration of groundwater processes is able to 
partially alleviate a warm and dry bias over the La Plata River basin of WRF without groundwater dynamics.

To consider the spatial and temporal variations associated with vegetation dynamics, we implemented high-resolution, satellite observations of green vegetation fraction (GVF) and leaf area index (LAI) obtained from the Moderate Resolution Imaging Spectroradiometer (MODIS). The MODIS LAI and GVF product (MYD15A2; Myneni et al. 2015) is an 8-day composite dataset with 1-km spatial resolution on a sinusoidal grid. We select the product that is closest to the middle of each month from 2003 to 2013 to represent the corresponding changing monthly vegetation dynamics throughout the simulation period.

We perform a 10 -yr continuous simulation for the period 2004-13 over the domain shown in Fig. 1, using lateral boundary conditions from ERA-Interim reanalysis dataset (Dee et al. 2011). The simulation has a horizontal resolution of $20 \mathrm{~km}$ and 40 levels in the vertical direction. WRF outputs are saved 4 times a day starting at 0000 UTC. Variables are saved as instantaneous values except for precipitation and ET, which are saved as accumulated values.

\section{b. Identification of CJEs}

A Chaco jet day is defined following the criterion described in Salio et al. (2002). The criterion is applied to grid cells immediately east of the Andes at around $25^{\circ} \mathrm{S}$. To be a CJE day it is required that at least one of the four daily saved time steps fulfill the following conditions: 1) wind speed at $850 \mathrm{hPa}$ must be equal to or greater than $12 \mathrm{~m} \mathrm{~s}^{-1} ; 2$ ) the difference of the wind speed between 850 and $700 \mathrm{hPa}$ must be larger than or equal to $6 \mathrm{~m} \mathrm{~s}^{-1}$ in some part enclosed by the $12 \mathrm{~m} \mathrm{~s}^{-1}$ isotach; and 3 ) the meridional component must be northerly and greater than the zonal component.

\section{Results}

\section{a. Comparison to reference datasets}

The spatial patterns of WRF-simulated climatological precipitation during the wet and dry seasons are compared with the Tropical Rainfall Measurement Mission (TRMM; Huffman et al. 2007) precipitation (Fig. 2). The temporal evolution of monthly mean regional precipitation over the Amazonian and La Plata basins are realistically represented. Linear correlation coefficients are over 0.9 for both regions when compared to the TRMM datasets. Compared to TRMM, WRF-derived austral warm season precipitation shows precipitation throughout the Amazonia with overestimation of precipitation over southeast Brazil and the South Atlantic convergence zone, which is the region of enhanced precipitation that extends from the
Amazon basin into the Atlantic (Nogués-Paegle and Mo 1997). Precipitation over the intertropical convergence zone is also overestimated by the WRF model and leads to stronger rainbands over the tropics in the austral dry season. It is known that the KF scheme tends to overestimate precipitation and has significant problems in the tropics (Kain 2004; Yang et al. 2012). However, currently the WRF tracers are only implemented with the KF scheme.

Evaluation of the WRF evapotranspiration is compared to the Global Land Evaporation Amsterdam Model (GLEAM; Miralles et al. 2011; Martens et al. 2017) evaporation dataset. The overall spatial pattern compares well with the GLEAM dataset and the correlation coefficient of monthly ET over the Amazon and La Plata are over 0.88, although this could be largely attributed to the seasonal cycle of ET. WRF-WVT warm season ET is overestimated over about the same region where precipitation is positively biased (e.g., southeast Brazil; see Fig. 2a), likely because of the precipitation bias in the model that leads to more evaporation.

However, reference datasets are also associated with uncertainties since they are based on bias-corrected assimilation products using observations. For instance, Wang and Wolff (2012) found that TRMM rain rates are in good agreement with ground radars at lower rain rates but become poor in the higher rain rates. Compared with in situ measurements, Yang et al. (2017) reported overestimation of forest ET in the GLEAM dataset. The scarcity of observation data over South America makes it even more difficult to obtain realistic ET estimates. Nevertheless, GLEAM is the best dataset available to perform continental-scale ET evaluation. In summary, comparisons with the reference datasets suggest that WRF-WVT is trustworthy although it overestimates ET and precipitation, and caution should be exercised when interpreting the results.

\section{b. Moisture transport over South America}

During the rainy December-February (DJF) season, approximately $28.2 \%$ of the precipitation in the Amazon comes from ET from the basin. There is a clear spatial gradient of increasing recycling toward the southwest of the basin (Fig. 3a). This pattern is consistent with previous results reported by Zemp et al. (2014) (see their Fig. 1). During the dry June-August (JJA) season, precipitation mostly occurs in the northern part of the domain due to the northward shift of the intertropical convergence zone (Fig. 2). Weakened easterly trade winds lead to less penetration of the Atlantic oceanic airmass and more stagnant environment over the Amazon. Due to the weaker synoptic forcing that drives the Amazon moisture to the south, the Amazon has a stronger local recycling of ET during the dry 


\section{Precipitation Comparison}
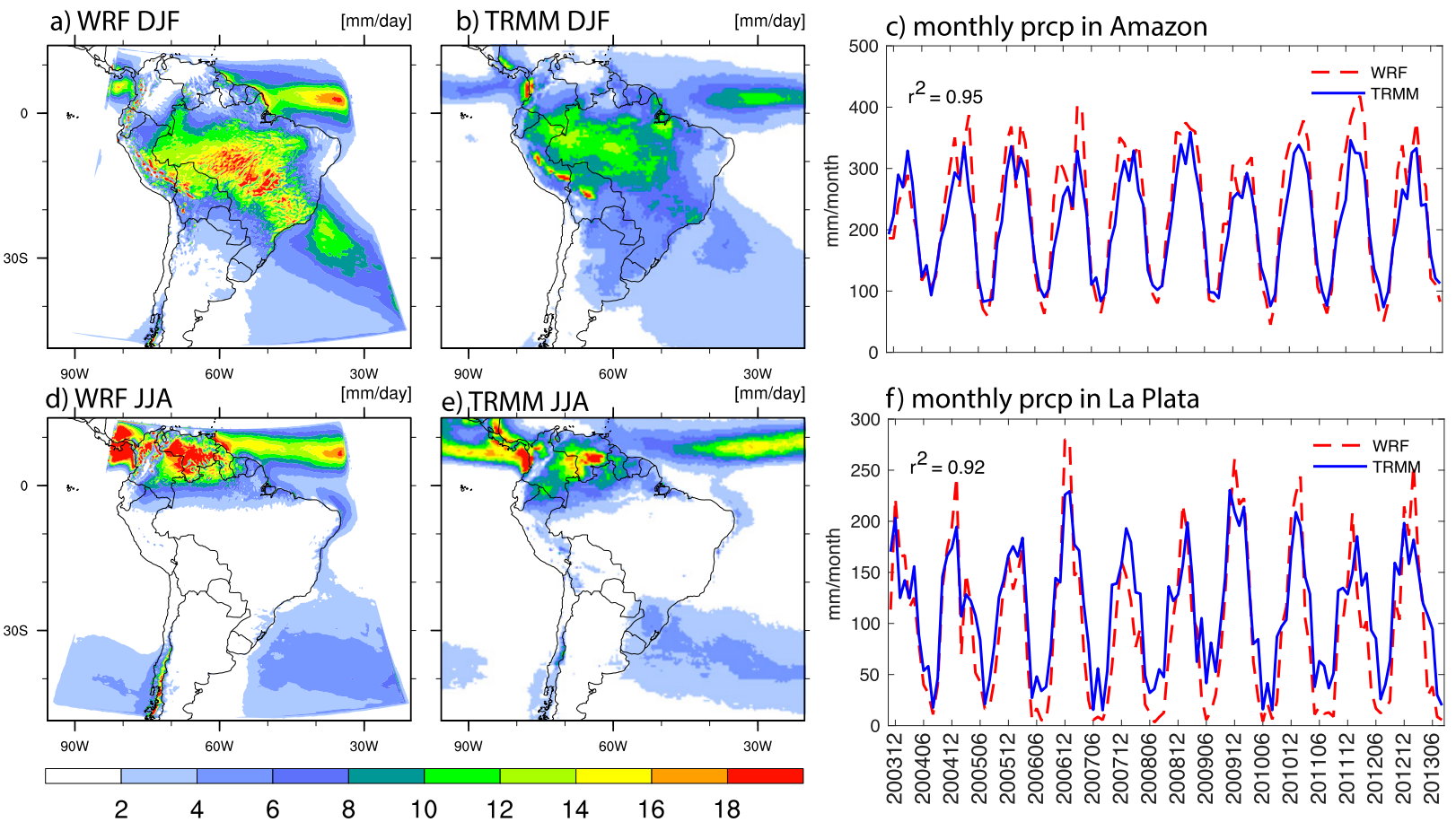

Evapotranspiration Comparison
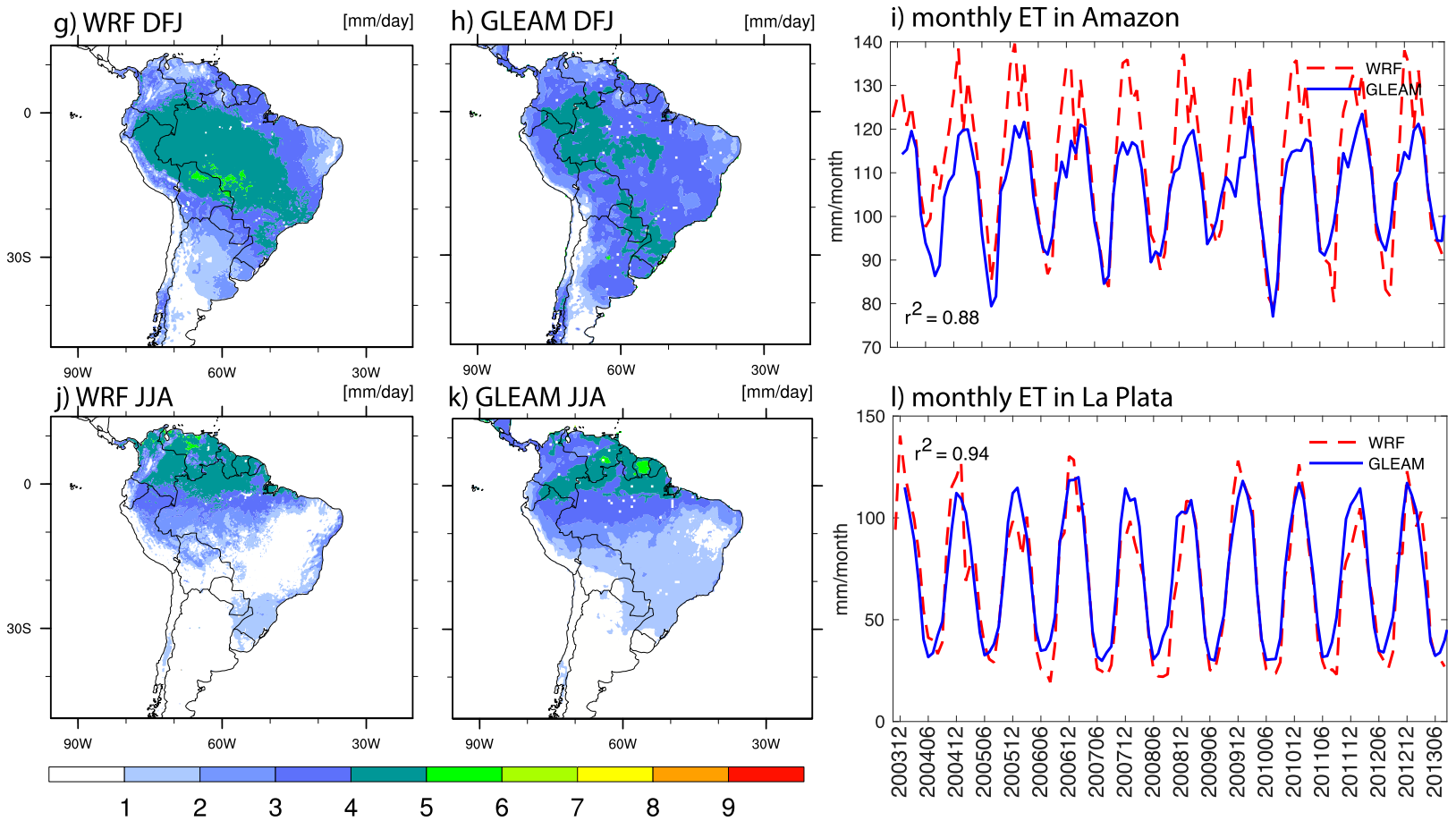

FIG. 2. The top panels show the spatial pattern of (a),(d) WRF simulated average daily precipitation in comparison with (b),(e) TRMM for both the wet and dry season, respectively. (c),(f) The area averaged monthly precipitation in the Amazon and La Plata; the red dashed line represents WRF and the blue line represents TRMM. The bottom panels show (g),(j) the WRF simulated average daily ET in comparison with (h),(k) GLEAM for both the wet and dry season, respectively. (i),(l) As in (c) and (f), but for ET. 
a) DJF $r_{p}$

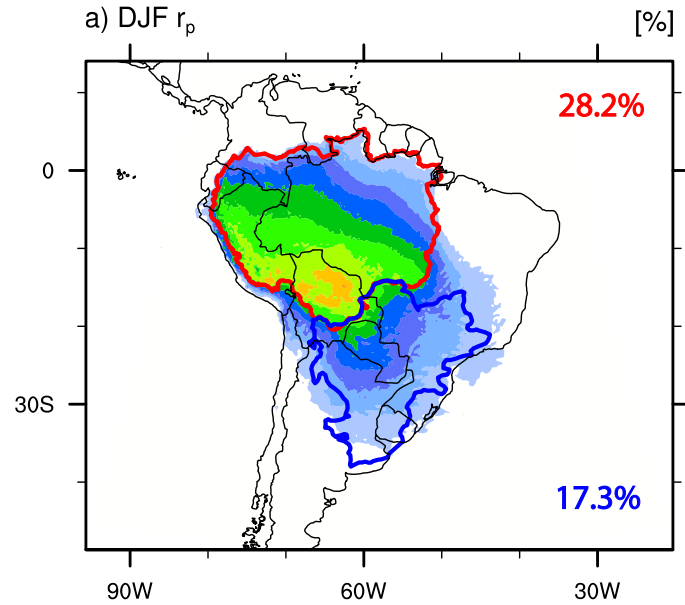

c) $J J A r_{p}$

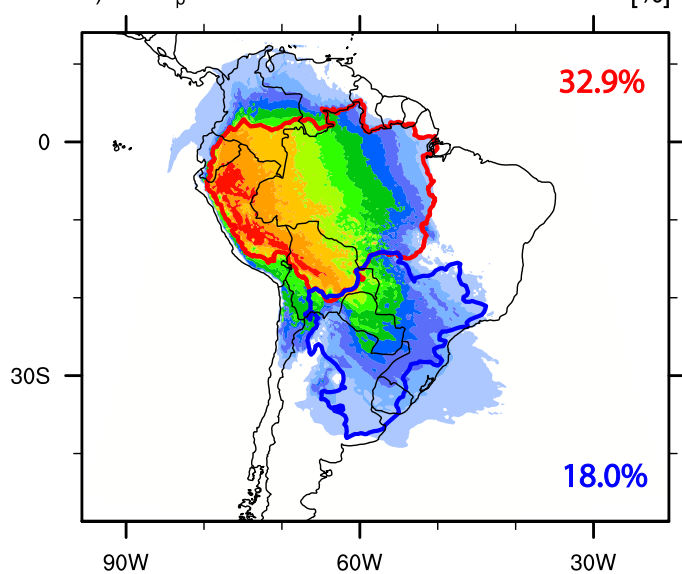

e) annual $r_{p}$ b) DJF $r_{p w}$

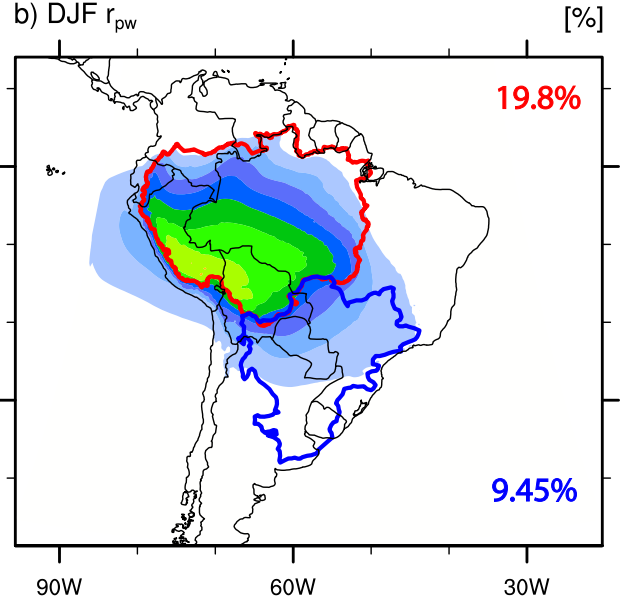

d) $J J A r_{p w}$

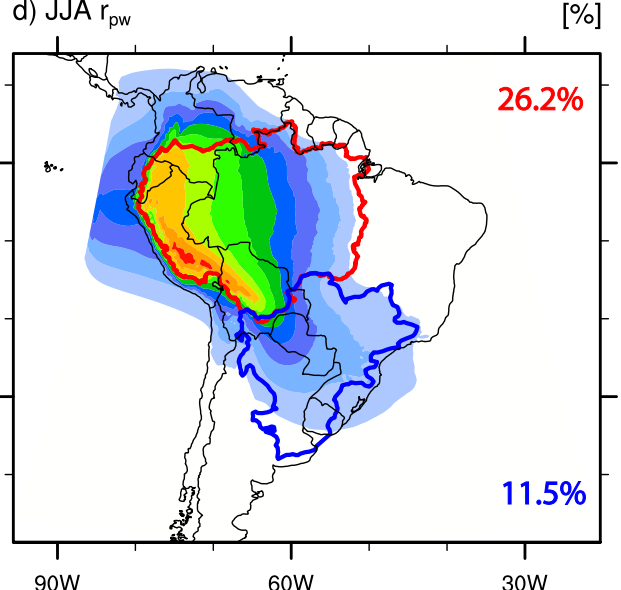

f) annual $r_{p w}$

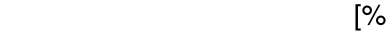

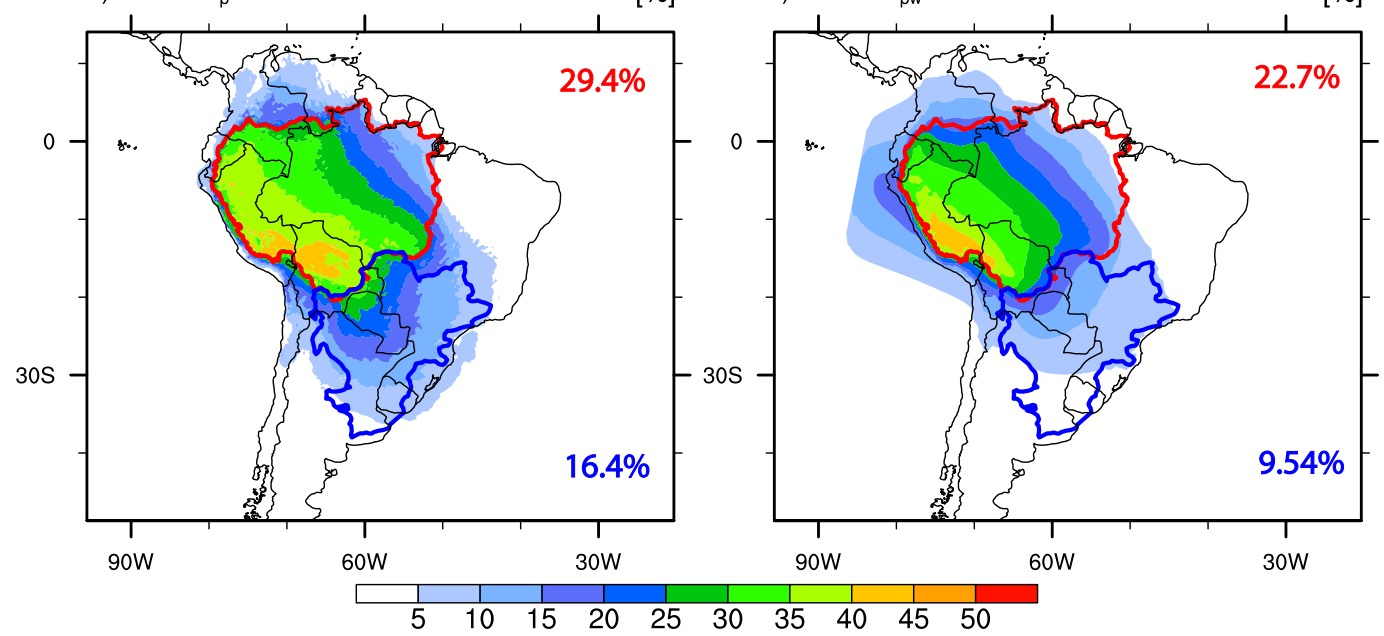

FIG. 3. (a) Spatial pattern of DJF tracer precipitation ratio $r_{p}$ from 2004 to 2013. (b) Spatial pattern of DJF integrated tracer water vapor ratio $r_{\mathrm{pw}}$ from 2004 to 2013. (c),(d) As in (a) and (b), but for JJA. (e),(f) Annual averages; red and blue numbers indicate the domain average value for the Amazon and La Plata, respectively.

season (Figs. 3c and 4a), with a domain average of 32.9\% during JJA.

Over the Amazon, $r_{p}$ (the ratio of tracer precipitation to total precipitation) is on average $29 \%$ over the $10-\mathrm{yr}$ period, consistent with previous estimates of $24 \%-35 \%$. Over the La Plata, $r_{p}$ is about $16 \%$, which is slightly less than previous estimates (Zemp et al. 2014; Martinez and Dominguez 2014). We also see that the precipitation ratio 

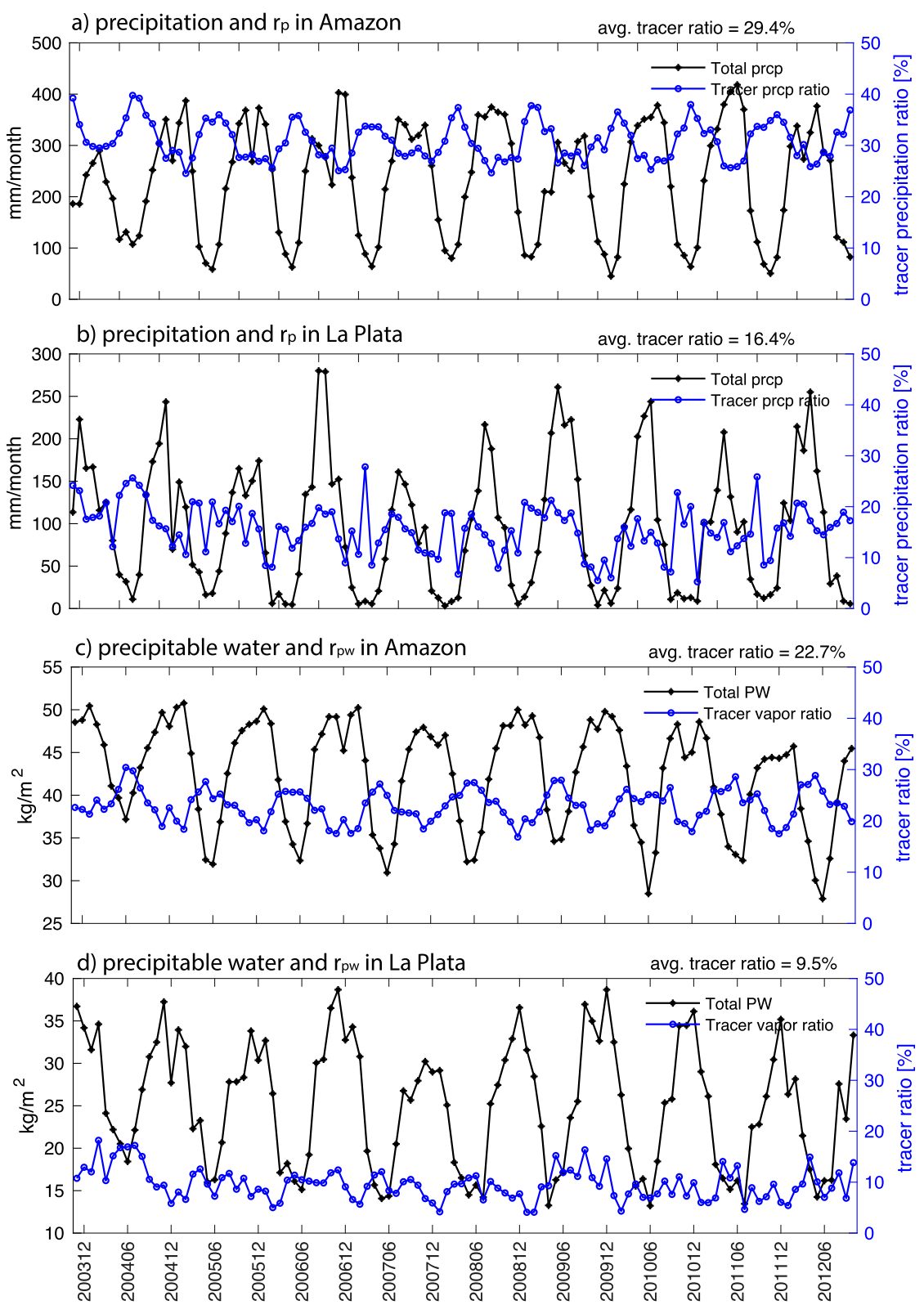

FIG. 4. (a) Precipitation that falls on the Amazon that originates from Amazonian ET. (b) Precipitation that falls on the LPRB that originates from Amazonian ET. (c) Precipitable water over the Amazon that originates from Amazonian ET. (d) Precipitable water over the LPBR that originates from Amazonian ET.

in the LPRB does not show the clear seasonal variations that are seen in the Amazon. Notably, the values of $r_{\mathrm{pw}}$ (the ratio of tracer precipitable water to total precipitable water) are considerably smaller, $-22.6 \%$ and $9.5 \%$ for the Amazon and LPRB, respectively. This is also seen when comparing values in different seasons. This raises an important point. In general, analytical recycling models that are based on the well-mixed assumption [such as the Dynamic Recycling Model (DRM) used in Martinez and
Dominguez (2014)] require that $r_{p}$ equals $r_{\mathrm{pw}}$, but our results show that the well-mixed assumption is not valid in this case. As further illustrated in Fig. 5, water vapor that evaporates from the Amazon tends to remain in the lower levels over the Amazon, but ascend as it moves southward (see Figs. 5b,d). Once the vapor is south of $20^{\circ} \mathrm{S}$ (it has left the Amazon basin) the tracer water vapor ratio shows higher values above $700 \mathrm{hPa}$. Despite the fact that the upper atmosphere has very low specific humidity, a significant 

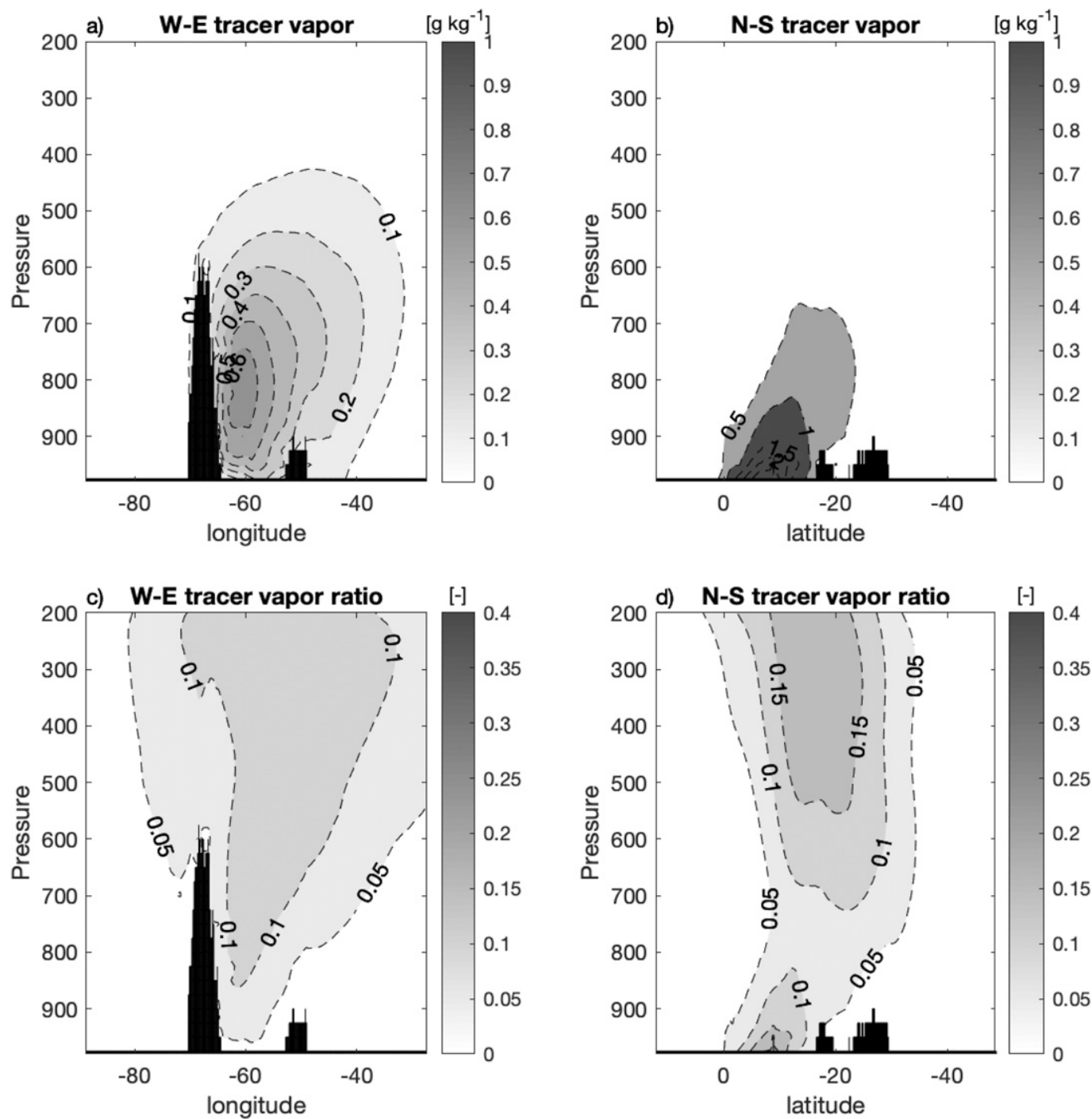

FIG. 5. (a) West-east cross section at $15^{\circ} \mathrm{S}$ of tracer water vapor mixing ratio $\left(\mathrm{g} \mathrm{kg}^{-1}\right)$. (b) North-south cross section at $60^{\circ} \mathrm{W}$ of tracer vapor mixing ratio $\left(\mathrm{g} \mathrm{kg}^{-1}\right)$. (c),(d) As in (a) and (b), but for tracer water vapor ratio.

portion of this humidity is of Amazonian origin. In the wellmixed scenario, the tracer vapor ratio should be vertically uniform, which is not seen in our experiments.

Tracer precipitation efficiency, defined as the ratio of tracer precipitation ratio to tracer precipitable water ratio $\left(e=r_{p} / r_{\mathrm{pw}}\right)$, is greater than 1 in the Amazon and LPRB. The physical implication is that moisture from the Amazon is more efficiently converted to precipitation than moisture from other sources. In fact, high efficiency of local moisture converting to precipitation in the Amazon, called "fast recycling," was proposed by Lettau et al. (1979). The process of fast recycling has been shown for many regions around the globe (Goessling and Reick 2013; Spracklen et al. 2012; van der Ent et al. 2013; Dominguez et al. 2016). The likely mechanism is that convection (or more specifically the model's convective parameterization) takes moisture from the lower atmosphere as the source for precipitation (Kain 2004). This is also supported by Fig. 5b, showing that the Amazon ET stays in the lower atmosphere and likely efficiently rains out in the tropical South America. The physical reason why Amazon moisture is so efficiently rained out in the LPRB is not as simple and will require further analysis in subsequent studies.

\section{c. Moisture transport to southern South America}

The previous section demonstrates that Amazon ET is an important source for precipitation over the La Plata River basin. Since the majority of precipitation over the $\mathrm{La}$ Plata is during the austral summer season, the following analyses will be focused on the summer months in DJF. 

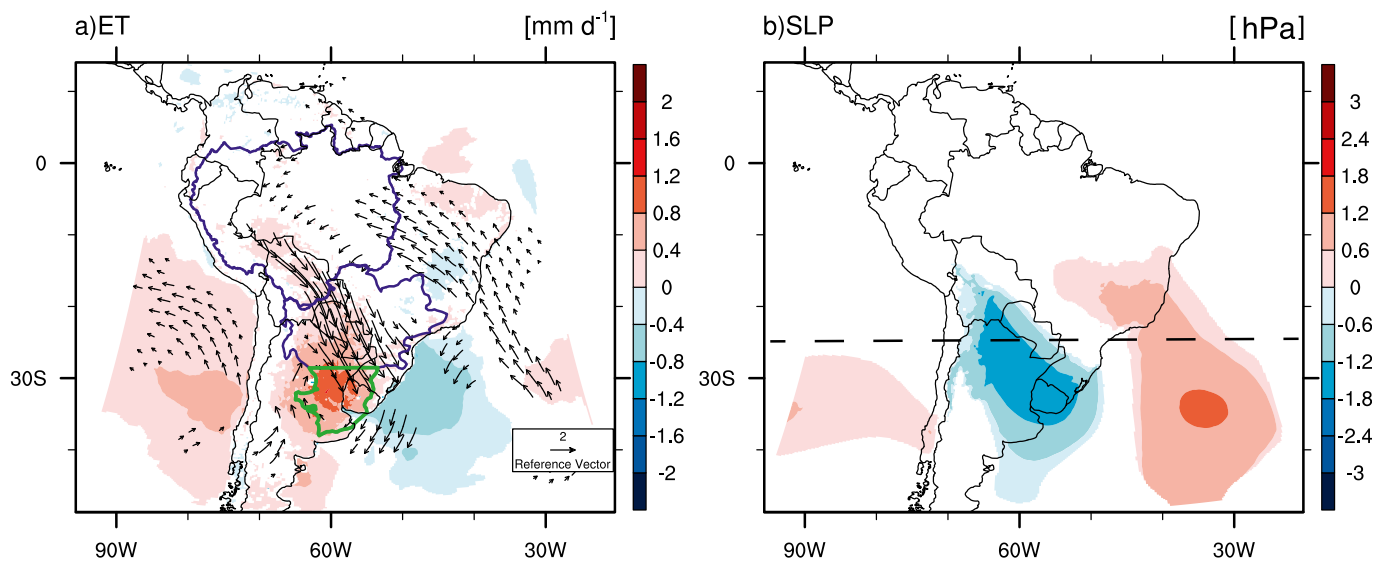

FIG. 6. (a) Wind at $850 \mathrm{hPa}$ and surface ET, and (b) sea level pressure (SLP) regressed on normalized precipitation over the southern La Plata (south of $28^{\circ} \mathrm{S}$; green outline). In (a), vectors show wind at $850 \mathrm{hPa}$; shading indicates ET ( $\mathrm{mm} \mathrm{day}^{-1}$ ). In (b), shading indicates SLP. Magnitude indicates rate of change with respect to a unit change in normalized precipitation. Only values significant at the $5 \%$ level are shown. The black dashed line indicates the location of the cross section in Fig. 7.

Precipitation over the southern La Plata (green outline in Fig. 6) shows a strong positive correlation with the wind patterns that transport Amazonian moisture to the south, while there is no strong correlation with the Amazon ET (Fig. 6). This indicates that although Amazonian ET is an important source for precipitation over southern South America, wind is the factor that controls the variability in the transport of moisture, while variability in Amazonian ET does not affect precipitation in LPRB.

To further analyze this, longitude-height cross sections of meridional moisture flux at $25^{\circ} \mathrm{S}$ are plotted for days with extreme high and low precipitation over southern La Plata [following Wei et al. (2016b)]. The meridional moisture flux $(q v)$ is expressed as a product of specific humidity $q$ and meridional wind $v$. If $q$ and $v$ are expressed as a sum of its mean and the transient eddy term, then

$q v=(\bar{q}+\Delta q)(\bar{v}+\Delta v)=\bar{q} \bar{v}+\bar{q} \Delta v+\bar{v} \Delta q+\Delta q \Delta v$.

The difference between the meridional moisture flux and its mean state is then given on the right-hand side of Eq. (2) below, representing difference induced by meridional wind change $(\bar{q} \Delta v)$, specific humidity change $(\bar{v} \Delta q)$, and a transient eddy term $(\Delta q \Delta v)$ :

$$
q v-\bar{q} \bar{v}=\bar{q} \Delta v+\bar{v} \Delta q+\Delta q \Delta v .
$$

Figure 7 shows the means in specific humidity $q$, meridional wind $v$, and three terms on the right-hand side of Eq. (2) during the wet and dry days over the southern La Plata. It is shown that the dominant changes can be attributed to the meridional wind (Figs. 7e,f). The meridional northerly wind is much stronger in the wet days and is responsible for the differences in meridional moisture transport during the wet and dry days over the southern La Plata.

To find out the factors that are associated with the strong meridional winds, we select a region $\left(20^{\circ}-30^{\circ} \mathrm{S}\right.$, $62.5^{\circ}-57.5^{\circ} \mathrm{W}$; green box in Fig. 8 a) that is along the lowlevel jet conveyor belt that transports moisture from the Amazon to the southern La Plata. Large-scale dynamical forcing and surface variables are examined to evaluate if there are significant correlations with the meridional winds over the chosen region (Fig. 8). At $900 \mathrm{hPa}$, the meridional wind in this region is strongly correlated with a low that is collocated with the NAL and a high off the coast of southeast Brazil. The specific pressure pattern facilitates the meridional winds. However, the low gradually diminishes with altitude (up to $700 \mathrm{hPa}$; not shown), implying its origin should be from the surface. The anomalous surface temperature corroborates its surface origin (Fig. 8d). At upper levels, the high and low center slightly shift to the southwest and become zonally oriented (not shown), resembling the anomaly pattern during CJEs shown in Salio et al. (2002) (see their Fig. 11). At the surface, soil moisture shows significant dry anomalies in northern Argentina, southeastern Brazil, and Paraguay. Anomalies over Brazil are likely linked to the reduced precipitation over the same region (Figs. 8b,c).

\section{d. Moisture transport during CJEs}

As discussed earlier, the South American low-level jet and specifically the CJE can transport Amazonian ET into southern South America. As described in section 2b, we use the methodology described in Salio et al. (2002) to identify the CJEs over the region. The number and the duration of CJEs simulated by WRF are shown in Fig. 9. In our results, 

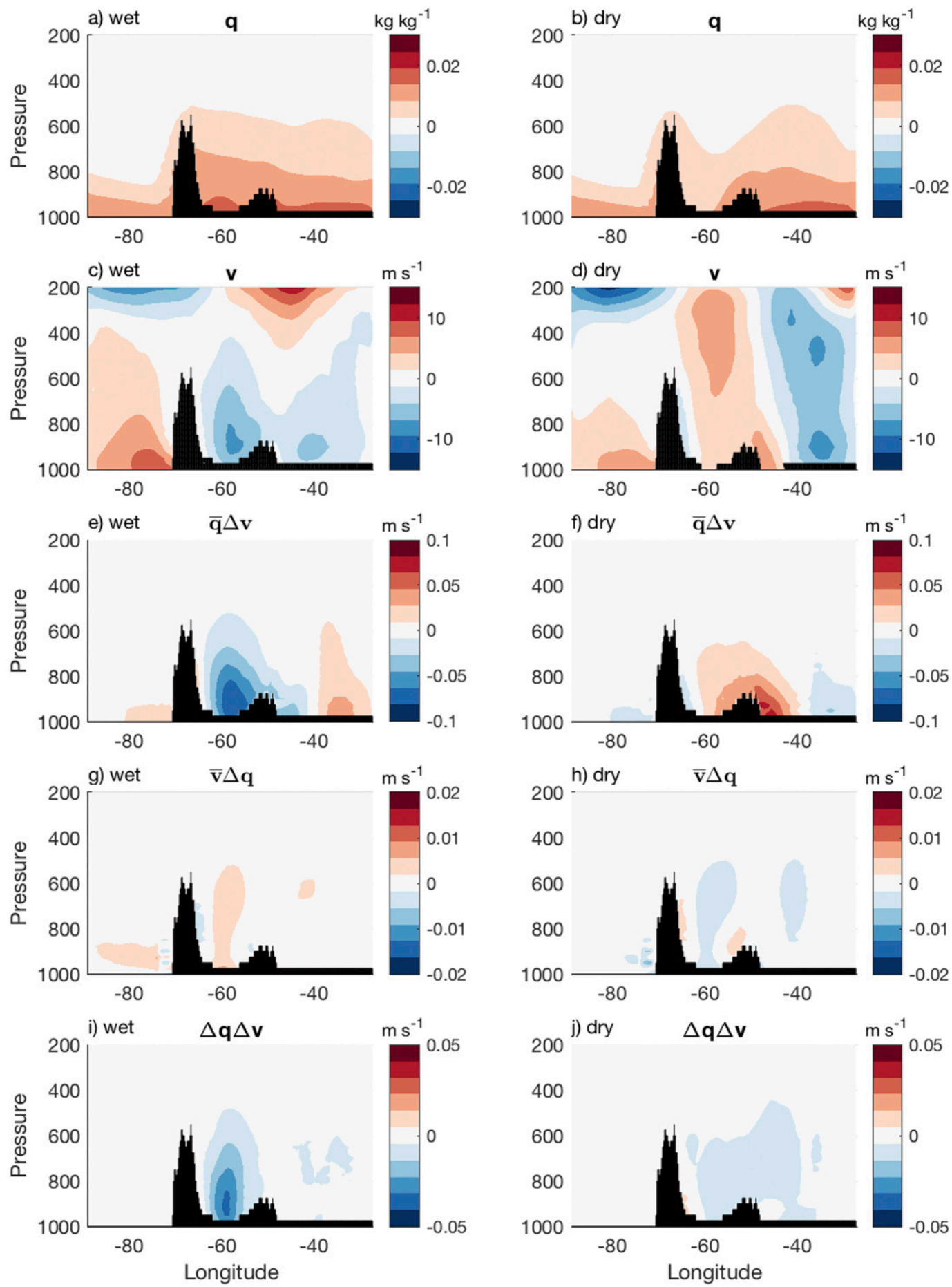

FIG. 7. West-east cross section of average (a),(b) specific humidity $q$, (c),(d) meridional winds $v$, and (e)-(j) moisture flux components [see Eq. (2)] for the (left) wettest and (right) driest days over the southern La Plata.

CJEs last 5 days or less and account for $16.1 \%$ of days during the austral summer season. This is very similar to the analysis of CJEs by Salio et al. (2002), indicating that WRFWVT is realistically representing this feature.
Once CJEs are identified, we can quantify the precipitation associated with each CJE. Figure 10a shows the ratio of precipitation during the CJEs to total precipitation in each grid cell. CJEs account for a large 
a) $\mathrm{GPH} 900 \mathrm{hPa}$

DJF

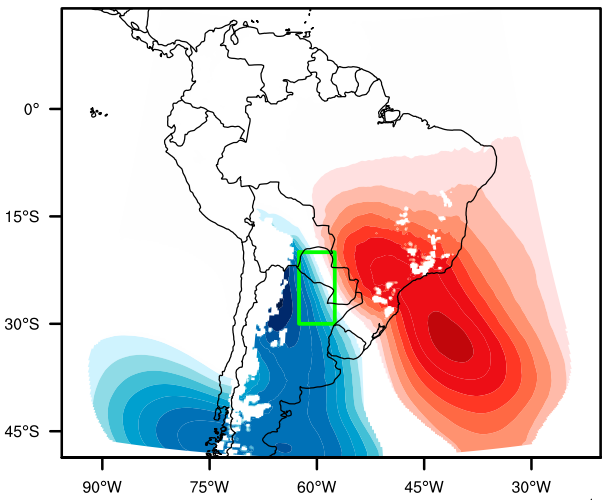

c) precipitation [m]

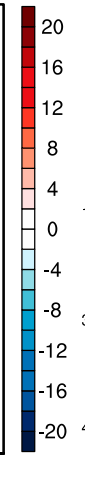

b) soil moisture

DJF

$\left[\mathrm{m}^{3} \mathrm{~m}^{-3}\right]$

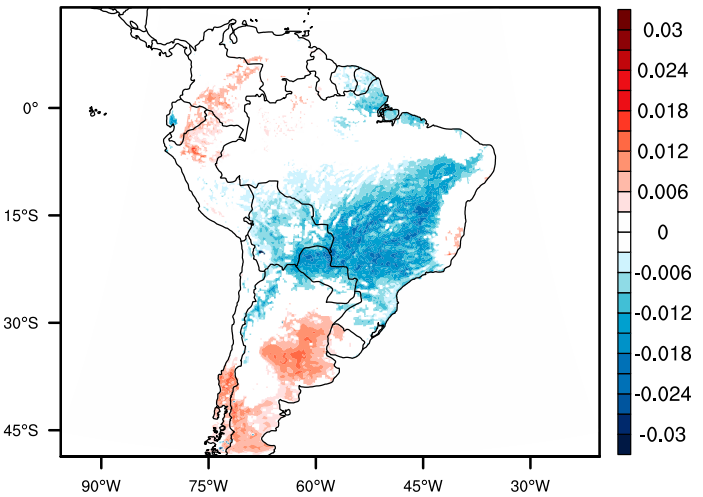

d) $T_{2 m}$

$[\mathrm{K}]$
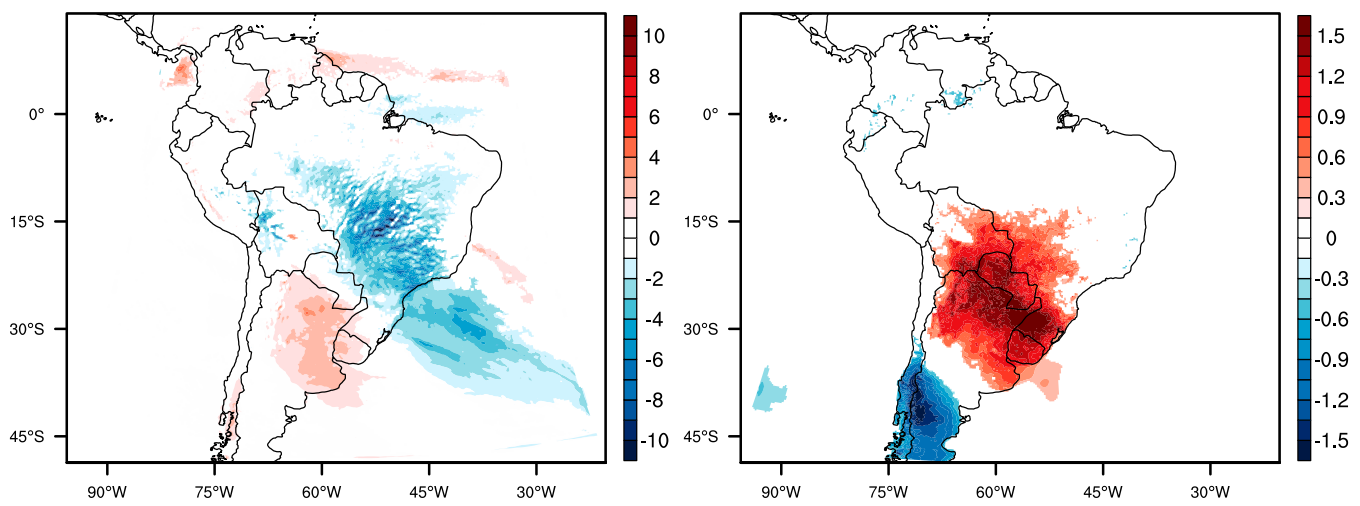

FIG. 8. (a) Geopotential height at $900 \mathrm{hPa}$, (b) soil moisture at the top soil layer, (c) precipitation, and (d) surface air temperature $T_{2 \mathrm{~m}}$ regressed on the normalized northerly winds over the green box in (a). Only values significant at the $5 \%$ level are shown.

portion of precipitation that falls over northeastern Argentina, with a local contribution up to $50 \%$. This indicates that CJEs are crucial for summer precipitation over the central and southern LPRB. During CJE episodes when meridional moisture fluxes are stronger and reach farther south than normal, LLJs with ample moisture are able to modulate the organization of mesoscale convective systems (MCSs), leading to large amount of precipitation in the southeastern South America (Salio et al. 2007). The ratio of tracer precipitation to total precipitation during the CJEs (Fig. 10b) is similar to the ratio pattern shown in Fig. 3a. This indicates that although meridional moisture flux during the CJEs is stronger than normal, the efficiency of this incoming moisture from Amazonian origin converting to precipitation remains the same as during normal conditions.

\section{e. The role of surface temperature and soil moisture in modulating CJEs}

\section{1) Composite AnAlysis of CJES}

To investigate the role of surface conditions on the formation of CJEs, anomalies in surface conditions near the NAL region including soil moisture and 2-m air temperature are analyzed. To rule out the impact of CJEs on the land surface, we extracted the land surface conditions 1 day before the CJEs. This will prevent CJE-related precipitation from affecting soil moisture. Additionally, CJEs have to be at least 5 days apart in

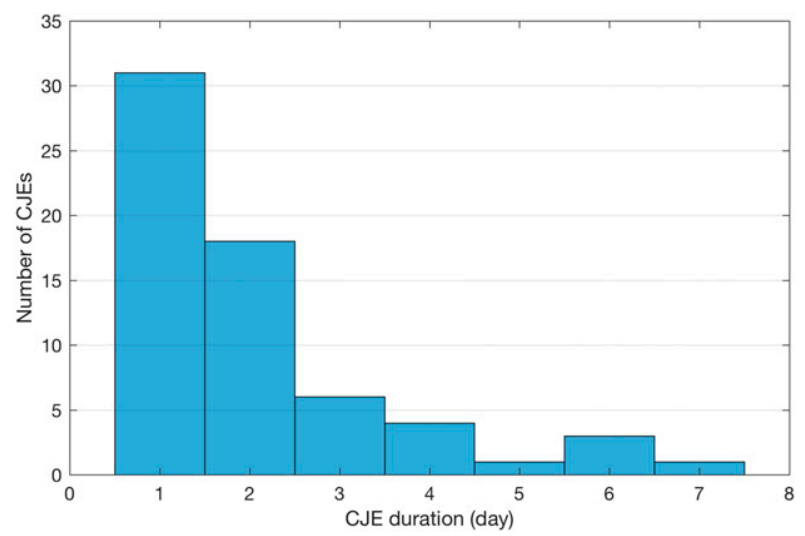

FIG. 9. CJE duration distribution simulated by the WRF-WVT for 2004-13. 


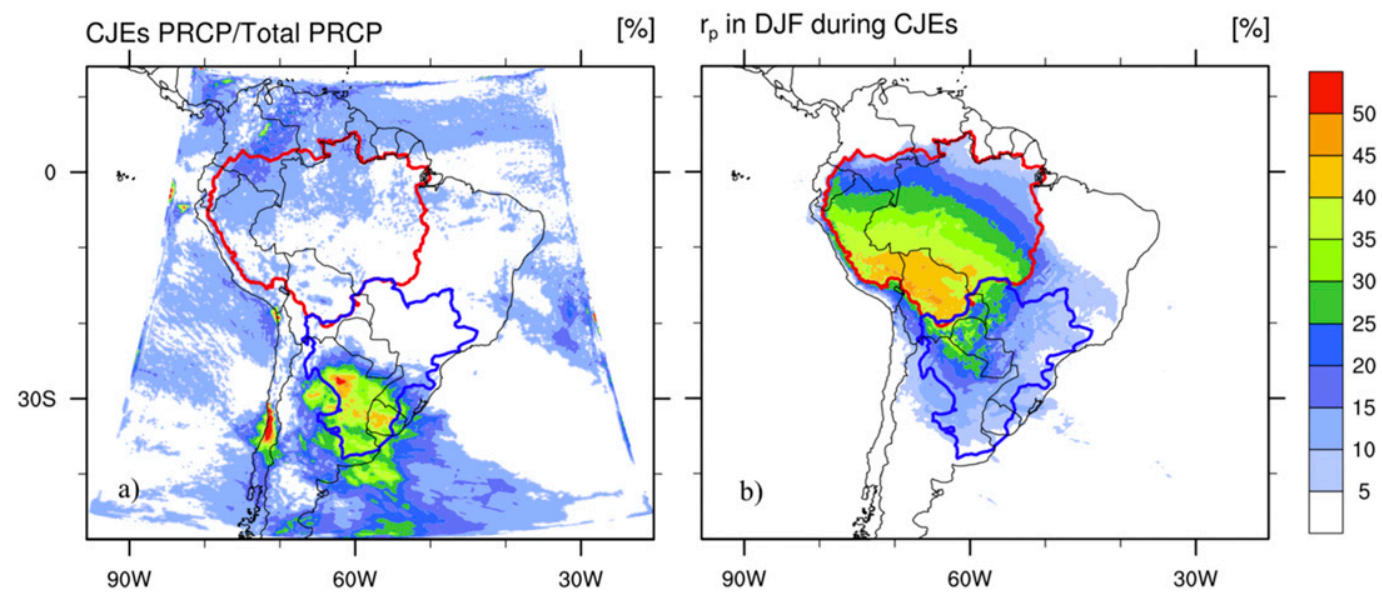

FIG. 10. (a) Ratio of precipitation during CJEs to total precipitation. (b) Tracer precipitation ratio $r_{p}$ during the CJEs.

order to minimize the impact of the previous CJEs on the surface fields.

Figures $11 \mathrm{a}$ and $11 \mathrm{~b}$ show the temperature and soil moisture composite anomaly fields 1 day before CJEs occur. A noticeable warm temperature anomaly is shown over northern Argentina and central and southwestern Brazil (Fig. 11a). Soil moisture anomalies show a similar pattern but with opposite sign (Fig. 11b), implying warmer air temperatures associated with drier soil moisture conditions before the arrival of the jets. This result confirms previous analysis of an individual CJE by Saulo et al. (2004), which shows that at the initial stage of a Chaco event, meridional intensification of the northerly wind is a response of the deepening of the northwestern Argentinean low. Analyzing individual events, Seluchi et al. (2003) argued that the northwestern Argentinean low during the austral summer is mainly dominated by local surface warming. The results shown here are consistent with the previous findings, although ours are based on composite analysis of CJEs occurring in a 10-yr simulation period rather than on individual events as reported previously. Note the disparity between the surface temperature and soil moisture anomaly patterns over northeastern Argentina, Uruguay, and southeastern Brazil, where anomaly does exist for the temperature, but not for the soil moisture field. This indicates that the warm anomaly should be due to temperature advection, instead of local warming. Figure 11c shows the spatial pattern of temperature advection anomaly 1 day before the CJEs and confirms that the anomaly is associated with warm temperature advection.

Analyzing the land surface and atmospheric conditions the day prior to the arrival of CJEs, we see that the land surface fluxes are characterized by higher sensible heat fluxes, lower latent heat fluxes, and lower surface specific humidity over northwestern Argentina (Figs. 12a-c).
There is a very broad region of anomalously high surface potential temperature (Fig. 12d) - this region is much larger than the region of increased sensible heat, indicating (again) that anomalous land surface fluxes are not the only mechanism responsible for the thermal anomaly. This agrees with our analysis in Fig. 11c. The increased surface temperatures are linked to a significantly deeper boundary layer and an increase in the lifting condensation level (Figs. 12e,f). There is also an increase in convective available potential energy (CAPE) and a decrease in level of free convection (Figs. 12g,h), which are favored for the formation of MCSs. These are consistent with the area where significant amount of precipitation falls that during the CJEs (Fig. 10a).

The effects on the overlying atmosphere shown in Fig. 12 can then translate into large-scale circulation patterns. The geopotential height anomaly at $900 \mathrm{hPa}$ during CJEs reveals that the anomalies are well collocated with the surface temperature anomalies shown in Fig. 13, with negative geopotential anomalies centered over northern Argentina (Fig. 13a). The thermal low anomaly is partly due to lowlevel heating and thermal advection, as can be inferred from low-level high temperature and the increased thickness between 900 and $600 \mathrm{hPa}$ (Figs. 11a,c and 13b). The anomalous high geopotential height anomaly at $900 \mathrm{hPa}$ northeast of the NAL strengthens the South Atlantic subtropical high, indicating that large-scale forcing is also playing a significant role in the CJEs. The specific geopotential anomaly pattern reinforces the northerly wind at the low levels.

\section{2) WRF SENSITIVITY EXPERIMENT OF SOIL MOISTURE}

To verify that soil moisture plays an important role in circulation patterns, a sensitivity experiment using WRF is conducted. We perturbed soil moisture over 

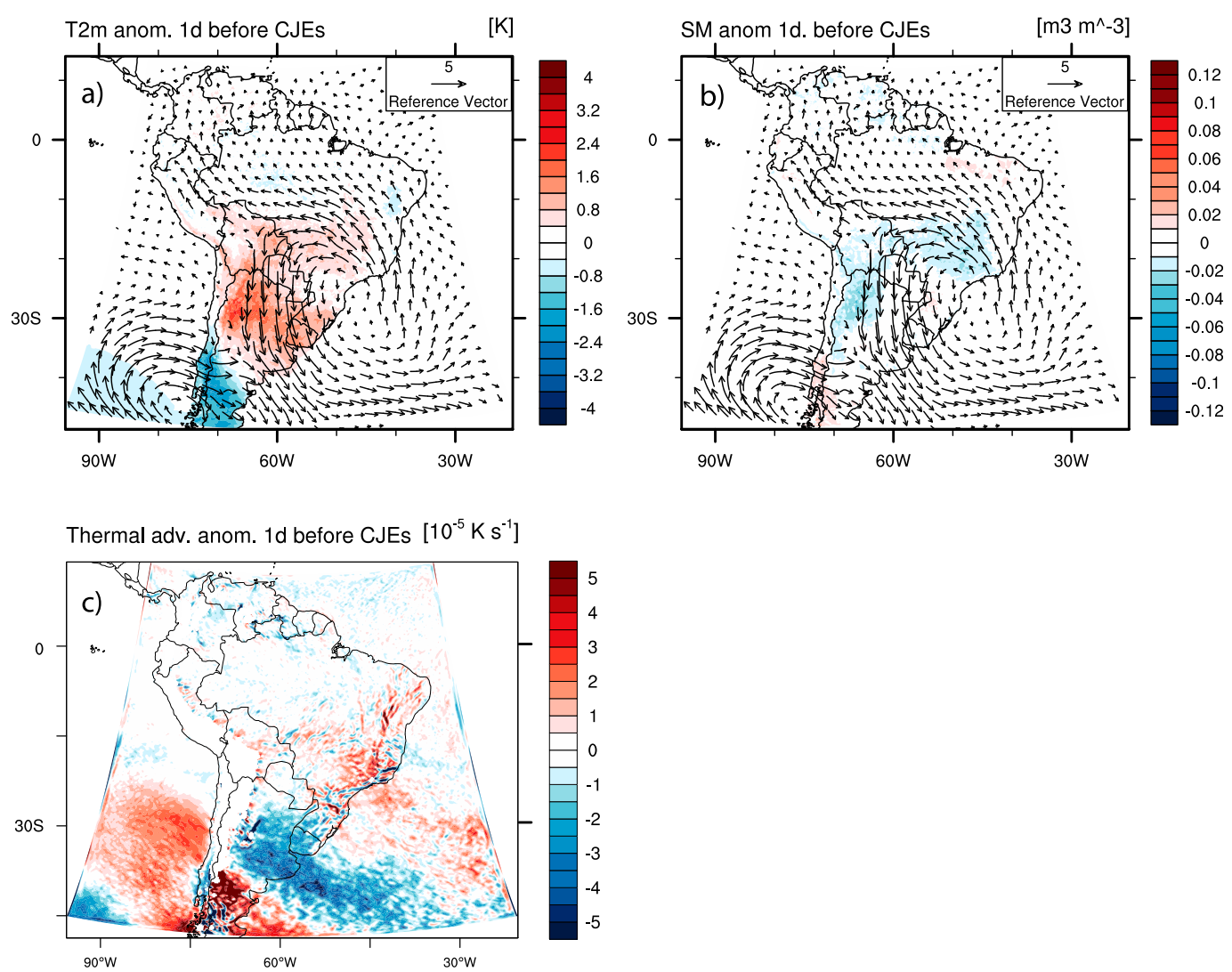

FIG. 11. (a) Surface air temperature $T_{2 \mathrm{~m}}$ anomaly (shaded) 1 day before the Chaco jet events. Arrow indicates the associated wind anomalies at $850 \mathrm{hPa}$. (b) Soil moisture (SM) anomaly (shaded) 1 day before the Chaco jet events. (c) Thermal advection anomaly at $850 \mathrm{hPa} 1$ day before the Chaco jet events. Note that local temperature change is negatively related to temperature advection following the temperature tendency equation.

northwestern Argentina (following Fig. 11b) to its field capacity and wilting point to represent wet and dry initial conditions. Studying land-atmosphere interaction over the South America, Saulo et al. (2010) had shown that soil moisture memory can last for a few days and then synoptic forcing took over. Therefore, 10-day simulations with dry and wet initial soil moisture conditions were performed, from 1 to 10 December in 2005, 2010, and 2011, respectively.

Differences between the dry and wet simulations indicate that dry initial soil moisture will induce a thermal low near the surface and intensify the surface meridional winds to the east of the NAL region (Figs. 14a,c,e). The intensified northerly winds occur generally at lower levels, although the vertical extent is slightly different among the three years (Figs. 14b,d,f). The sensitivity experiment proved that dry soil moisture over the NAL region can cause a surface low and induce northerly wind anomalies to the east of the NAL region and consequently affect moisture transport deeper to higher latitudes. It is important to highlight that, as we have shown above, the NAL seems to be affected by a combination of soil moisture anomalies and warm air advection. We are not incorporating the effects of temperature advection in these simulations.

Differences in precipitation between the dry and wet simulation indicate a southward shift of the precipitation pattern (not shown), likely induced by the enhanced low-level northerlies in the dry simulation. This confirms the role of dry soil moisture anomaly over northwest Argentina in promoting precipitation over southern South America.

\section{Summary and conclusions}

In this study, a 10-yr simulation of the South American climate is performed using WRF with WVT. The ET that comes out of the Amazonian basin is tagged during the simulation. Our results show that about $28 \%$ of the Amazon precipitation comes from local precipitation recycling during the wet season, but about $33 \%$ of the dry-season precipitation is of local recycling. Over the LPRB, about $16 \%$ of precipitation originates from Amazonian ET, without a discernable seasonal cycle. 

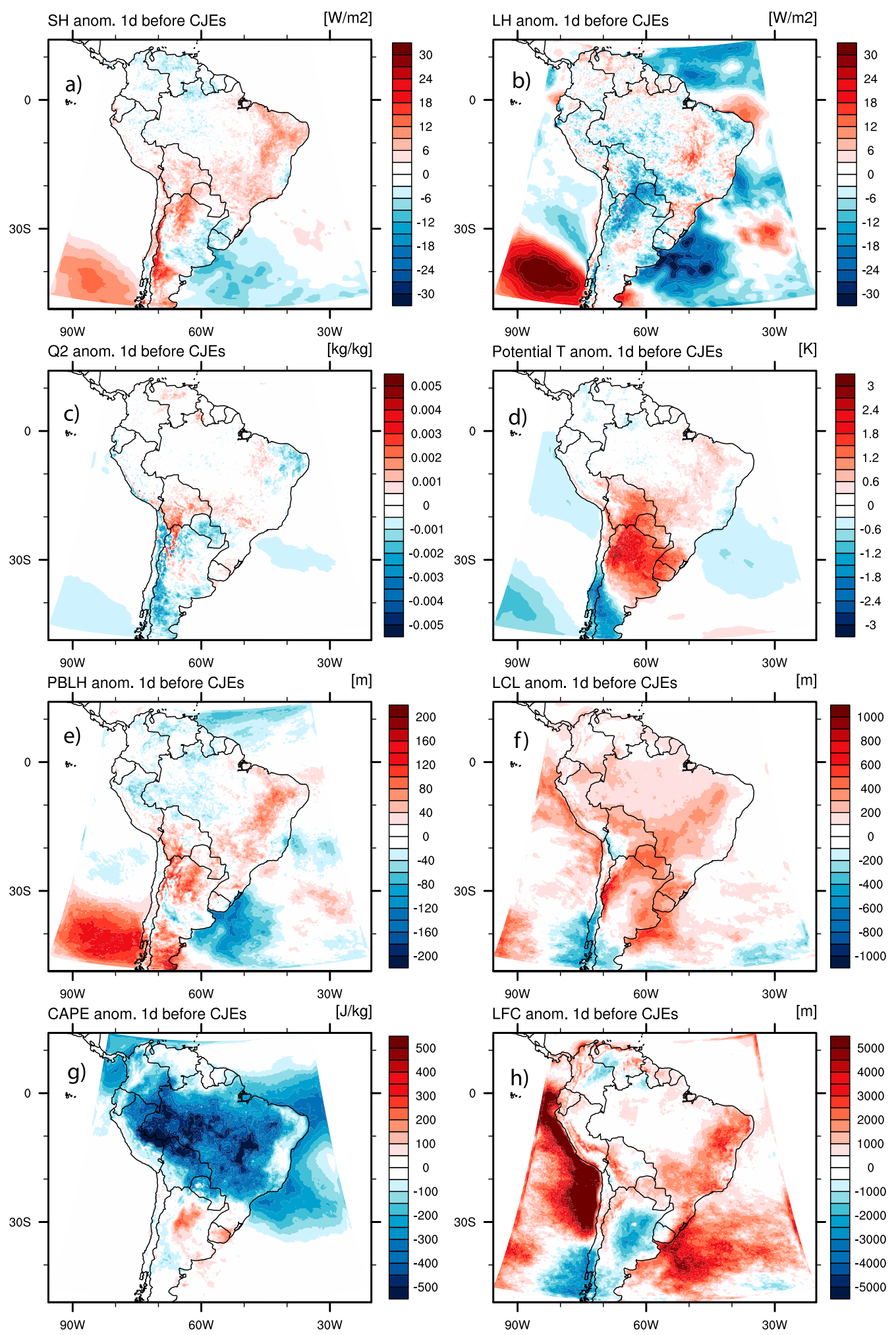

FIG. 12. Anomalies of (a) sensible heat flux, (b) latent heat flux, (c) specific humidity at $2 \mathrm{~m}$, (d) potential temperature, (e) planetary boundary layer depth (PBLH), (f) lifting condensation level (LCL), (g) convective available potential energy (CAPE), and (h) level of free convection (LFC), 1 day before the CJEs. 

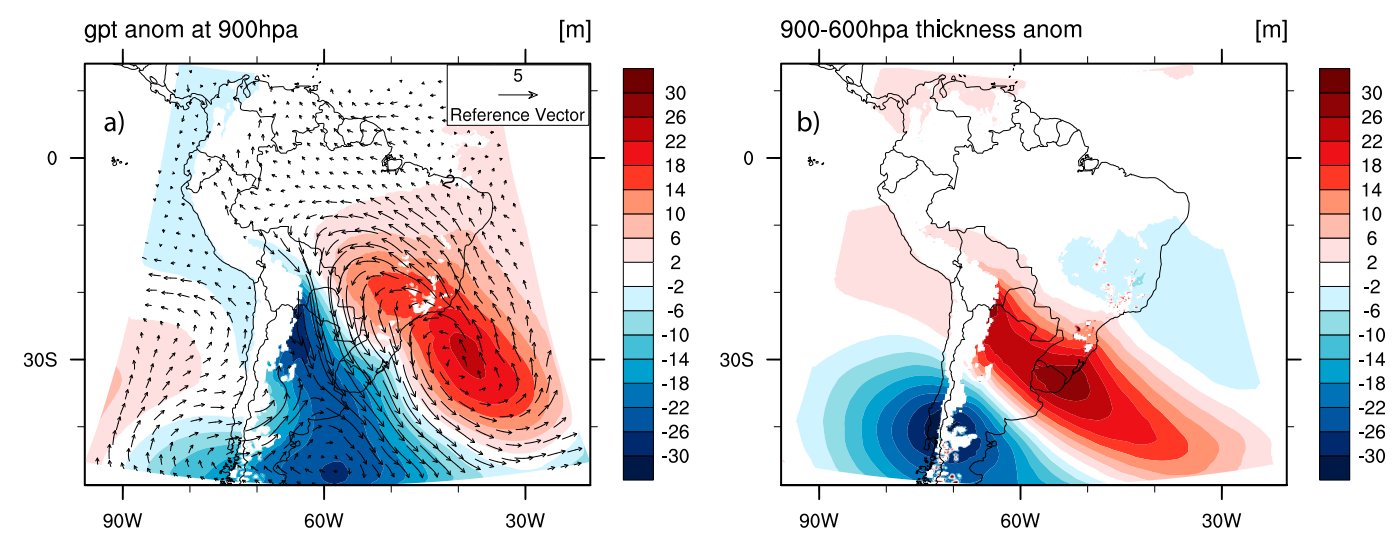

FIG. 13. Geopotential height anomalies during the CJEs at $900 \mathrm{hPa}$ and the thickness anomalies of 900-600 hPa.

While our recycling values over the Amazon are similar to previous studies, the precipitation over the LPRB that originates from Amazonian ET is lower than estimates of previous studies $[23 \%$ in Dirmeyer et al. (2009b); 24\% in Martinez and Dominguez (2014)]. We believe this discrepancy could be in part due to the simplifying assumptions of the models used in previous studies. For example, the Dynamic Recycling Model used in Martinez and Dominguez (2014) uses the wellmixed assumption and is likely underestimating the amount of Amazonian ET that exits the continent toward the Atlantic at higher latitudes. Our results show that the well-mixed assumption used by previous analytical models is not accurate because the ratio of precipitable water that originates from the Amazon is less than the ratio of precipitation that originates from the Amazon. This indicates that Amazonian moisture is very efficiently rained out of the column.

Nevertheless, we also noted the deficiencies associated with our WRF simulations. Overestimation of precipitation and ET is likely associated with the KF convective parameterization. As a result, the amount of tracer moisture would be overestimated and likely affect precipitation recycling over the Amazon and the amount of tracer moisture transported to higher latitudes. Coupling the tracer to the other convective parameterizations, or performing convective-resolving simulations, is worth further investigation.

By using regional climate models, some of the physical processes that are responsible for moisture transport to southern South America have been identified. The CJEs are periods during which meridional winds can reach poleward of $25^{\circ} \mathrm{S}$. Analyzing land surface and atmospheric conditions on the day prior to CJE arrivals we highlight a mechanism by which the land surface can modulate CJEs. We find that dry surface conditions and high sensible heat fluxes are associated with higher temperatures over northwestern Argentina. Antecedent surface high temperatures extend over a very large region that extends beyond the region of dry soil moisture conditions. The high temperatures can be explained by warm advection over northeastern Argentina, Uruguay, and southeastern Brazil. The high temperatures result in direct influence on the overlying boundary layer, and at large scale generate a deepening of the surface low pressure, clearly visible at the $900-\mathrm{hPa}$ geopotential height level. This geopotential height anomaly pattern, also known as the NAL, is able to reinforce the low-level northwesterly winds, and partly explains the intensity of CJEs. Critically, more than half of the precipitation occurs during CJEs over part of the LPRB, when strong meridional moisture transport occurs. Although we naturally caution that our composite analysis cannot provide proof of causality, a sensitivity experiment using WRF confirms that dry soil moisture over the NAL region would induce a thermal low and subsequently enhance the northerly winds. It is also clear that in addition to soil moisture anomalies, temperature advection plays an important role in the anomalous high surface temperatures.

In summary, two of the possible ways that the land surface can affect precipitation are 1) by changing the amount of moisture available for precipitation (moisture recycling) and 2) by changing the atmospheric thermal structure and consequently affecting circulation patterns. When focusing on precipitation over the LPRB, our results suggest that the second mechanism is critically important as land surface conditions over the western LPRB can modify the thermal structure of the overlying atmosphere, intensifying continental-scale circulation patterns (namely, the LLJ), and can subsequently impact precipitation in the southern LPRB. On the other hand, when analyzing the first mechanism, we find that the fraction of precipitation that originates from Amazonian ET and rains over northern Argentina remains close to $16 \%$, even during CJEs. It has long 

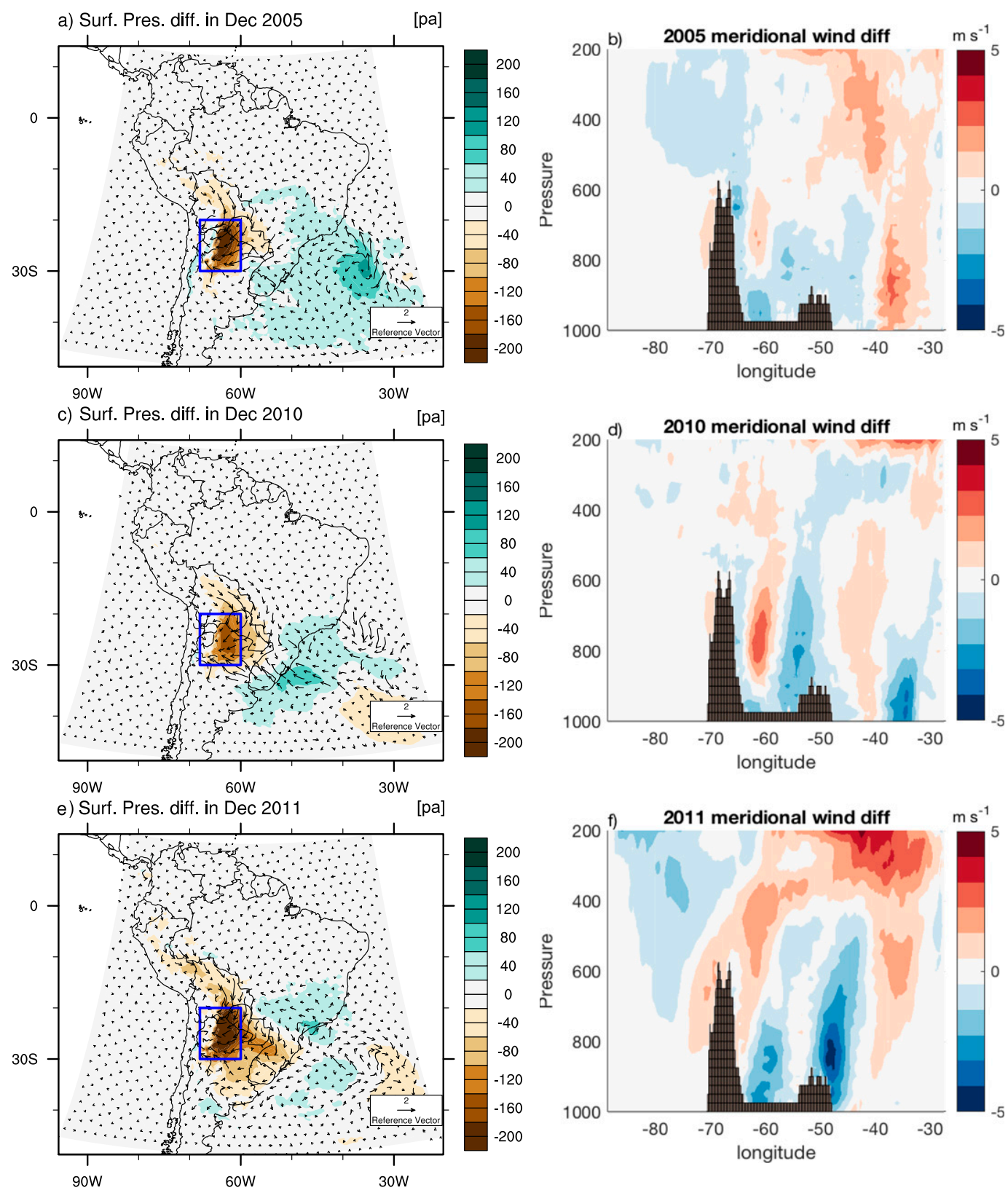

FIG. 14. (left) Difference between the dry and wet WRF simulations in surface pressure (shading; Pa) and 10-m surface winds ( $\mathrm{m} \mathrm{s}^{-1}$ ) for (a) 2005, (c) 2010, and (e) 2011. (right) Longitude-pressure cross section at $25^{\circ} \mathrm{S}$ of the meridional wind difference between the dry and wet simulations. Negative values indicate stronger northerly winds. The blue box shown here indicates the region where soil moisture has been perturbed between the wet and dry simulations.

been thought that the role of the low-level jet is to bring moisture from the Amazon to higher latitudes. However, our analysis shows that the moisture from the Amazon is only a small fraction of the precipitable water and precipitation. Where does the remaining $84 \%$ come from? The two likely candidates are the Atlantic Ocean and the LPRB itself. Our future work will try to address this question.
Acknowledgments. This research was supported by National Science Foundation (NSF) CAREER Award AGS 1454089. We thank G. Miguez-Macho for providing the WRF-WVT code. The National Center for Supercomputing Applications (NCSA) at the University of Illinois provided computational support through a Blue Waters allocation. Part of the analysis performed by Z. Y. at the Pacific Northwest National Laboratory was 
supported by the Office of Science of the U.S. Department of Energy (DOE) as part of the Atmospheric System Research (ASR) Program via Grant KP1701000/57131. The authors declare no conflict of interests.

\section{REFERENCES}

Arraut, J. M., C. Nobre, H. M. J. Barbosa, G. Obregon, and J. Marengo, 2012: Aerial rivers and lakes: Looking at largescale moisture transport and its relation to Amazonia and to subtropical rainfall in South America. J. Climate, 25, 543-556, https://doi.org/10.1175/2011JCLI4189.1.

Barlage, M., M. Tewari, F. Chen, G. Miguez-Macho, Z.-L. Yang, and G.-Y. Niu, 2015: The effect of groundwater interaction in North American regional climate simulations with WRF/ Noah-MP. Climatic Change, 129, 485-498, https://doi.org/ 10.1007/s10584-014-1308-8.

Brubaker, K. L., D. Entekhabi, and P. S. Eagleson, 1993: Estimation of continental precipitation recycling. J. Climate, 6, 1077-1089, https:// doi.org/10.1175/1520-0442(1993)006<1077:EOCPR>2.0.CO;2.

Cook, B. I., G. B. Bonan, and S. Levis, 2006: Soil moisture feedbacks to precipitation in southern Africa. J. Climate, 19, 41984206, https://doi.org/10.1175/JCLI3856.1.

Dee, D. P., and Coauthors, 2011: The ERA-Interim reanalysis: Configuration and performance of the data assimilation system. Quart. J. Roy. Meteor. Soc., 137, 553-597, https://doi.org/10.1002/qj.828.

Dirmeyer, P. A., and K. L. Brubaker, 2006: Evidence for trends in the Northern Hemisphere water cycle. Geophys. Res. Lett., 33, L14712, https://doi.org/10.1029/2006GL026359.

$\longrightarrow$, and - 2007: Characterization of the global hydrologic cycle from a back-trajectory analysis of atmospheric water vapor J. Hydrometeor., 8, 20-37, https://doi.org/10.1175/JHM557.1.

—, C. A. Schlosser, and K. L. Brubaker, 2009a: Precipitation, recycling, and land memory: An integrated analysis. J. Hydrometeor. 10, 278-288, https://doi.org/10.1175/2008JHM1016.1.

_ , K. L. Brubaker, and T. DelSole, 2009b: Import and export of atmospheric water vapor between nations. J. Hydrol., 365, 1122, https://doi.org/10.1016/j.jhydrol.2008.11.016.

Dominguez, F., G. Miguez-Macho, and H. Hu, 2016: WRF with water vapor tracers: A study of moisture sources for the North American monsoon. J. Hydrometeor., 17, 1915-1927, https:// doi.org/10.1175/JHM-D-15-0221.1.

Eltahir, E. A. B., 1998: A soil moisture-rainfall feedback mechanism: 1 . Theory and observations. Water Resour. Res., 34, 765776, https://doi.org/10.1029/97WR03499.

— , and R. L. Bras, 1994: Precipitation recycling in the Amazon basin. Quart. J. Roy. Meteor. Soc., 120, 861-880, https:// doi.org/10.1002/qj.49712051806.

Findell, K. L., and E. A. B. Eltahir, 1997: An analysis of the soil moisture-rainfall feedback, based on direct observations from Illinois. Water Resour. Res., 33, 725-735, https://doi.org/10.1029/ 96WR03756.

— and 2003: Atmospheric controls on soil moistureboundary layer interactions. Part I: Framework development. J. Hydrometeor., 4, 552-569, https://doi.org/10.1175/ 1525-7541(2003)004<0552:ACOSML > 2.0.CO;2.

Gimeno, L., A. Drumond, R. Nieto, R. M. Trigo, and A. Stohl, 2010: On the origin of continental precipitation. Geophys. Res. Lett., 37, L13804, https://doi.org/10.1029/2010GL043712.

_ continental precipitation. Rev. Geophys., 50, RG4003, https:// doi.org/10.1029/2012RG000389.
Goessling, H. F., and C. H. Reick, 2013: On the "well-mixed" assumption and numerical 2-D tracing of atmospheric moisture. Atmos. Chem. Phys., 13, 5567-5585, https://doi.org/10.5194/ acp-13-5567-2013.

Hong, S.-Y., and H.-L. Pan, 1996: Nonlocal boundary layer vertical diffusion in a medium-range forecast model. Mon. Wea. Rev., 124, 2322-2339, https://doi.org/10.1175/1520-0493(1996)124<2322: NBLVDI $>2.0 . \mathrm{CO} ; 2$

—, and J.-O. J. Lim, 2006: The WRF single-moment 6-class microphysics scheme (WSM6). J. Korean Meteor. Soc., 42, 129-151.

$\mathrm{Hu}, \mathrm{H}$., and F. Dominguez, 2015: Evaluation of oceanic and terrestrial sources of moisture for the North American monsoon using numerical models and precipitation stable isotopes. J. Hydrometeor., 16, 19-35, https://doi.org/10.1175/JHM-D14-0073.1.

Huffman, G. J., and Coauthors, 2007: The TRMM Multisatellite Precipitation Analysis (TMPA): Quasi-global, multiyear, combined-sensor precipitation estimates at fine scales. J. Hydrometeor., 8, 38-55, https://doi.org/10.1175/JHM560.1.

Insua-Costa, D., and G. Miguez-Macho, 2018: A new moisture tagging capability in the Weather Research and Forecasting model: Formulation, validation and application to the 2014 Great Lake-effect snowstorm. Earth Syst. Dyn., 9, 167-185, https://doi.org/10.5194/esd-9-167-2018.

Kain, J. S., 2004: The Kain-Fritsch convective parameterization: An update. J. Appl. Meteor., 43, 170-181, https://doi.org/ 10.1175/1520-0450(2004)043<0170:TKCPAU>2.0.CO;2.

— training plume model and its application in convective parameterization. J. Atmos. Sci., 47, 2784-2802, https://doi.org/ 10.1175/1520-0469(1990)047<2784:AODEPM>2.0.CO;2.

Koster, R. D., and Coauthors, 2004: Regions of strong coupling between soil moisture and precipitation. Science, 305, 11381140, https://doi.org/10.1126/science.1100217.

— , and Coauthors, 2006: GLACE: The Global Land-Atmosphere Coupling Experiment. Part I: Overview. J. Hydrometeor., 7, 590-610, https://doi.org/10.1175/JHM510.1.

—, Y. Chang, H. Wang, and S. D. Schubert, 2016: Impacts of local soil moisture anomalies on the atmospheric circulation and on remote surface meteorological fields during boreal summer: A comprehensive analysis over North America. J. Climate, 29, 7345-7364, https://doi.org/10.1175/JCLI-D-160192.1 .

Lettau, H., K. Lettau, and L. C. B. Molion, 1979: Amazonia's hydrologic cycle and the role of atmospheric recycling in assessing deforestation effects. Mon. Wea. Rev., 107, 227-238, https://doi.org/ 10.1175/1520-0493(1979)107<0227:AHCATR >2.0.CO;2.

Marengo, J. A., 2006: On the hydrological cycle of the Amazon Basin: A historical review and current state-of-the-art. Rev. Bras. Meteor., 21, 1-19.

Martens, B., and Coauthors, 2017: GLEAM v3: Satellite-based land evaporation and root-zone soil moisture. Geosci. Model Dev., 10, 1903-1925, https://doi.org/10.5194/gmd-10-1903-2017.

Martinez, J. A., and F. Dominguez, 2014: Sources of atmospheric moisture for the La Plata River Basin. J. Climate, 27, 67376753, https://doi.org/10.1175/JCLI-D-14-00022.1.

— _ _ , and G. Miguez-Macho, 2016: Impacts of a groundwater scheme on hydroclimatological conditions over southern South America. J. Hydrometeor., 17, 2959-2978, https:// doi.org/10.1175/JHM-D-16-0052.1.

Miguez-Macho, G., Y. Fan, C. P. Weaver, R. Walko, and A. Robock, 2007: Incorporating water table dynamics in climate 
modeling: 2. Formulation, validation, and soil moisture simulation. J. Geophys. Res., 112, D13108, https://doi.org/10.1029/ 2006JD008112.

—, A. Rios-Entenza, and F. Dominguez, 2013: The impact of soil moisture and evapotranspiration fluxes on the spring water cycle in the Iberian Peninsula: A study with moisture tracers in WRF. 2013 Fall Meeting, San Francisco, CA, Amer. Geophys. Union, Abstract H12B-05.

Miralles, D. G., T. R. H. Holmes, R. A. M. De Jeu, J. H. Gash, A. G. C. A. Meesters, and A. J. Dolman, 2011: Global landsurface evaporation estimated from satellite-based observations. Hydrol. Earth Syst. Sci., 15, 453-469, https://doi.org/ 10.5194/hess-15-453-2011.

Myneni, R., Y. Knyazikhin, and T. Park, 2015: MYD15A2 MODIS/ Aqua Leaf Area Index/FPAR 8-Day L4 Global 1km SIN Grid. NASA LP DAAC. Accessed 31 May 2017, https:/ladsweb. modaps.eosdis.nasa.gov/missions-and-measurements/products/ MYD15A2/.

Nepstad, D., and Coauthors, 2009: The end of deforestation in the Brazilian Amazon. Science, 326, 1350-1351, https://doi.org/ 10.1126/science. 1182108 .

Niu, G.-Y., and Coauthors, 2011: The community Noah land surface model with multiparameterization options (Noah-MP): 1 . Model description and evaluation with local-scale measurements. J. Geophys. Res., 116, D12109, https://doi.org/10.1029/ 2010JD015139.

Nogués-Paegle, J. and K. C. Mo, 1997: Alternating wet and dry conditions over South America during summer. Mon. Wea. Rev., 125, 279-291, https://doi.org/10.1175/1520-0493(1997) $125<0279$ :AWADCO $>2.0 . \mathrm{CO} ; 2$.

Pal, J. S., and E. A. B. Eltahir, 2001: Pathways relating soil moisture conditions to future summer rainfall within a model of the landatmosphere system. J. Climate, 14, 1227-1242, https://doi.org/ 10.1175/1520-0442(2001)014<1227:PRSMCT >2.0.CO;2.

Ruscica, R. C., A. A. Sörensson, and C. G. Menéndez, 2015: Pathways between soil moisture and precipitation in southeastern South America. Atmos. Sci. Lett., 16, 267-272, https:// doi.org/10.1002/asl2.552.

Salati, E., A. Dall'Olio, E. Matsui, and J. R. Gat, 1979: Recycling of water in the Amazon Basin: An isotopic study. Water Resour. Res., 15, 1250-1258, https://doi.org/10.1029/WR015i005p01250.

Salio, P., M. Nicolini, and A. C. Saulo, 2002: Chaco low-level jet events characterization during the austral summer season. J. Geophys. Res., 107, 4816, https://doi.org/10.1029/2001JD001315.

$\longrightarrow,-$, and E. J. Zipser, 2007: Mesoscale convective systems over southeastern South America and their relationship with the South American low-level jet. Mon. Wea. Rev., 135, 12901309, https://doi.org/10.1175/MWR3305.1.

Santanello, J. A., and Coauthors, 2018: Land-atmosphere interactions: The LoCo perspective. Bull. Amer. Meteor. Soc., 99, 1253-1272, https://doi.org/10.1175/BAMS-D-17-0001.1.

Saulo, A. C., M. E. Seluchi, and M. Nicolini, 2004: A case study of a Chaco low-level jet event. Mon. Wea. Rev., 132, 2669-2683, https://doi.org/10.1175/MWR2815.1.

— L. Ferreira, J. Nogués-Paegle, M. Seluchi, and J. Ruiz, 2010: Land-atmosphere interactions during a northwestern Argentina low event. Mon. Wea. Rev., 138, 2481-2498, https:// doi.org/10.1175/2010MWR3227.1.

Seluchi, M. E., A. C. Saulo, M. Nicolini, and P. Satyamurty, 2003: The northwestern Argentinean low: A study of two typical events. Mon. Wea. Rev., 131, 2361-2378, https://doi.org/ 10.1175/1520-0493(2003)131<2361:TNALAS > 2.0.CO;2.

Soares-Filho, B. S., and Coauthors, 2006: Modelling conservation in the Amazon basin. Nature, 440, 520-523, https://doi.org/ 10.1038/nature04389.

Sodemann, H., H. Wernli, and C. Schwierz, 2009: Sources of water vapour contributing to the Elbe flood in August 2002-A tagging study in a mesoscale model. Quart. J. Roy. Meteor. Soc., 135, 205-223, https://doi.org/10.1002/qj.374.

Spracklen, D. V., S. R. Arnold, and C. M. Taylor, 2012: Observations of increased tropical rainfall preceded by air passage over forests. Nature, 489, 282-285, https://doi.org/10.1038/ nature11390.

Taylor, C. M., A. Gounou, F. Guichard, P. P. Harris, R. J. Ellis, F. Couvreux, and M. De Kauwe, 2011: Frequency of Sahelian storm initiation enhanced over mesoscale soil-moisture patterns. Nat. Geosci., 4, 430-433, https://doi.org/10.1038/ngeo1173.

van der Ent, R. J., H. H. G. Savenije, B. Schaefli, and S. C. SteeleDunne, 2010: Origin and fate of atmospheric moisture over continents. Water Resour. Res., 46, W09525, https://oi.org/ 10.1029/2010WR009127.

, O. A. Tuinenburg, H. R. Knoche, H. Kunstmann, and H. H. G. Savenije, 2013: Should we use a simple or complex model for moisture recycling and atmospheric moisture tracking? Hydrol. Earth Syst. Sci., 17, 4869-4884, https:// doi.org/10.5194/hess-17-4869-2013.

Vera, C., and Coauthors, 2006: The South American Low-Level Jet Experiment. Bull. Amer. Meteor. Soc., 87, 63-77, https:// doi.org/10.1175/BAMS-87-1-63.

Wang, J., and D. B. Wolff, 2012: Evaluation of TRMM rain estimates using ground measurements over central Florida. J. Appl. Meteor. Climatol., 51, 926-940, https://doi.org/ 10.1175/JAMC-D-11-080.1.

Wei, J., H. Su, and Z.-L. Yang, 2016a: Impact of moisture flux convergence and soil moisture on precipitation: A case study for the southern United States with implications for the globe. Climate Dyn., 46, 467-481, https://doi.org/10.1007/s00382-0152593-2.

-, Q. Jin, Z.-L. Yang, and P. A. Dirmeyer, 2016b: Role of ocean evaporation in California droughts and floods. Geophys. Res. Lett., 43, 6554-6562, https://doi.org/10.1002/2016GL069386.

Wright, J. S., R. Fu, J. R. Worden, S. Chakraborty, N. E. Clinton, C. Risi, Y. Sun, and L. Yin, 2017: Rainforest-initiated wet season onset over the southern Amazon. Proc. Natl. Acad. Sci. USA, 114, 8481-8486, https://doi.org/10.1073/pnas.1621516114.

Yang, B., Y. Qian, G. Lin, R. Leung, and Y. Zhang, 2012: Some issues in uncertainty quantification and parameter tuning: A case study of convective parameterization scheme in the WRF regional climate model. Atmos. Chem. Phys., 12, 2409-2427, https://doi.org/10.5194/acp-12-2409-2012.

Yang, X, B. Yong, L. Ren, Y. Zhang, and D. Long, 2017: Multi-scale validation of GLEAM evapotranspiration products over China via ChinaFLUX ET measurements. Int. J. Remote Sens., 38, 5688-5709, https://doi.org/10.1080/01431161.2017.1346400.

Zemp, D. C., C. F. Schleussner, H. M. J. Barbosa, R. J. van der Ent, J. F. Donges, J. Heinke, G. Sampaio, and A. Rammig, 2014: On the importance of cascading moisture recycling in South America. Atmos. Chem. Phys., 14, 13337-13359, https:// doi.org/10.5194/acp-14-13337-2014. 